\title{
Application of Learning Materials Design for Hindu Religious Subject in Special Education
}

\author{
Desak Putu Saridewi ${ }^{1}$, Paula Dewanti ${ }^{2}$ \\ \{desakputusaridewi@gmail.com ${ }^{1}$,pdewanti@gmail.com ${ }^{2}$ \} \\ Universitas Pendidikan Ganesha, Indonesia
}

\begin{abstract}
Distinctive schools have been built intended for students with special needs. However, not all teachers be given a particular education/training to accommodate the requirement. Taken place in SLB Pembina Mataram, this study focused on Hindu Religious Education and how its design of learning material can be applied for students with special needs. It is also cover the issues and constraints faced and how to overcome the obstacles occur. Approach used in this study is descriptive qualitative, structured participant observation, an open-ended interview, including documentation. Data are collected and analysed by data reduction methods, data presentation, and data interpretation that are analysed by Ausubel's Theory.Despite all shortcomings, application of Hindu Religious learning material design continues to be developed. Through an effort which combined with individual approaches and be synergizing with parents in learning, made children be able to understand their religion and grow as an individual with character.
\end{abstract}

Keywords: Design of Learning, Hindu Religious Subject, Learning Material, Special Education

\section{Introduction}

The right of each citizen to obtain education is emphasized in 1945 Constitution article 31 paragraph 1, explicitly, the right to gain an education without exception, comprise normal, physically challenges or special needs [11].

West Nusa Tenggara Government policy set decree on opening special school for chlidren with special needs, where special education unit solely based on the needs of community as citizens domiciled in the West Nusa Tenggara region.

Those government's attention raises great hopes for children of Indonesia, especially children with special needs.

The reality is that even though schools have been built, phenomenon that occurs is not all teachers in that special schools, school for children with special needs, especially Hindu Religious Education teachers receive specific education/training to accommodate children with different inability.

The fact is that the need for human resources, especially Hindu Religious Education teachers in schools for children with special needs is very much needed.

Second problem discovered during this study was that Hindu Religious Education for students with special needs has not been highlighted by curriculum at Higher Education for Religion. Students did not received specific lecture material focused to students with special 
needs. In reality, Religious Education at school for children with special needs must be carried out and a mandatory as it is foundation of other general subjects.

The above phenomenon has not been highlighted by Indonesia government. Based on that, researchers are interested in researching the Application of Design Learning Materials for Hinduism in a Schools of Children with Special Needs [12]. It is importance for religious teacher candidates to master competencies more on children with special needs, so that children experience a fun religious learning, thus applied correctly, and children are expected to be children who have good character, even though within their limitations.

In respond to this phenomenon, researchers are attentive in researching the design of learning materials applied at Government School of SLB Negeri Pembina Mataram to support West Nusa Tenggara government in equitable education, as well creating an opportunity for an equal conduct for Indonesian children without discrimination.

Teacher knowledgein learning process of children with special needs in early stage is essential. It is an addition to the laws and regulations that support the implementation of conceptual education of children with special needs and scientific studies on child development.

Results of this study contribute to science, specifically Hinduism education science in designing learning material of Hindu Religious subject for children with special needs at the level of preparation/early childhood [5] [7]. This can also be used as a conduit to provide descriptions relating to issues that widen in education. For Hindu education observers, in general, it provides an overview of how to bundle and apply religious learning materials design in schools for children with special needs.

\section{Method}

Approach used in this study is descriptive qualitative, structured participant observation, an open-ended interview, including documentation. Data are collected and analysed by data reduction methods, data presentation, and data interpretation that are analysed by Ausubel's Theory.

Cognitive Learning Theory stated by Ausubel mentioned that students will learn well if the content of the lesson is defined and presented properly, so as to influence student learning progress. Learning purpose will be effectively achieved if teacher's knowledge of learning content is adequate. Teacher has to be able to find very abstract, general and inclusive information about what will be taught. Educators or teachers must have a good logical thinking in order to sort out the learning material, formulate it in a clear and concise, as well put it in logical and easily understood structures.

Design Application of Hindu Learning Materials made varied with images, videos, information technology, real objects that refer to regular school curriculum. In fact, it is designed and applied to adjust with the conditions of students with special needs.Habitual methods and individual approaches are the mainstays in SLB Pembina Mataram. Teacher has to be able to create social interactions between students so that as early as possible embraces mutual respect between human beings and grows together among fellows, build up their religious values by starting to know their religion, ways of praying, learning, playing and other activities.

Design is procedure for carrying out a process. Design as a problem-solving process where the purpose of a design is to achieve the best solution in solving problems. Another 
word, a design arises because of human needs to solve a problem.Using a design, people can take systematic steps to solve a problem at hand. Thus, a design is basically a linear process that starts from the determination of needs which then developed into a design to respond to those needs, which are then tested. It ends with an evaluation process that carried out to determine the results of the design. The research data set can be accessed in osf.io Open Science Framework.

\section{Discussion}

\subsection{Application of Design of Learning Materials for Hindu Religious Education}

Embeding religious values from an early age in school for children with special needs at preparation stage, equivalent to early childhood learning, is an early stage of learning process in the world of education.Education that makes children who have deficiencies becomes confident in facing their future so that it is necessary to highlight[5] [6].

A proper application of Hindu Religious learning that suits the needs of students is a priority for attracting children's compassion for Hindu Religious values learning with a concept of fun way at the school for children with special needs.

An early appropriate learning has a positive impact and constitute as initial foundation for cultivation of moral values/goodness to lead to a better life for future generations.

Design is a procedure performed in carrying out a process.Design as a problem solving process, which purpose to achieve best solution in solving problems. Therefore, a design arises because of human need to solve a problem [2].

Teacher self-development in designing learning materials for preparation level, elementary school (SD), up to senior high (SMALB), requires intensive assistance so that learning activities run in accordance with the objectives set. In facing complex problems towards objectives set, is also require planning in designing learning materials. First step would be to collect as much information as possible, directly or indirectly, that related to learning to be taught, adjusted to the vision, mission and profile of school for children with special needs [2]. Secondly, after the material information is considered adequate, then there are several alternatives made by a teacher to design learning materials that are relatively ready to be presented to students. That is including: 1). Material design in the form of a list of material topics arranged in a narrative and linear manner in accordance with the desired topic.2). Material design in the form of an image with a map concept. The map concept will be more interesting. It displays images of material concepts that arranged in accordance with the nature of science itself, regardless the order of topics that are desired [4]. Learning material is adjusted and linked to real life and also to the themes taught, so that it will always be remembered in student long-term memory and can be applied in their daily life.

Hindu Religious learning has a method or technique of cultural education with a position to sit quietly and meditate (silent sitting), praying, lecture, discussion and role play (story telling), singing, and group work (group activity)[3] [9]. While education material includes the growth of religious attitudes (Sradha and Bhakti) by giving a real life examples, with methods of habituation, both excuted in the family, school and in community [8].

In line with cultural educationdevelopment, children with special needs, as early as possible, can be applied in accordance with the method of sitting quietly before learning process started, learnto pray, listening to lectures, or listening to video of religious stories. A 
video (with sign language) that tells about attitudes of a Hindu good character that can be imitated by children and a character that is not good that cannot be imitated.

Application of learning material design at level of preparation, or equivalent to early childhood is just as important. It is how teachers are able to generate social interactions among students so that as early as possible embraces mutual respect among human beings, grows together with human values through praying, playing, learning and other activities.

Teaching system leads to an individualization system. Types of inability of individual students at Government School of SLB Negeri Pembina Mataram were hearing disorder (Tunarungu), mentally retarded (Tunagrahita), disabled (Tunadaksa) and autistic (Autis). The curriculum used for basic level has adjusted to its specificity [1] [7].Learning activities were executed individually, in groups, and classically according to their different abilities. Type of approaching used is also more into an individualized approach.Inaddition to learning activities, in the context of rehabilitation at the SDLB (Elementary School) special treatments are also carried out in accordance with child's needs.

Tunagrahita or children with mental disorder receive self-care services; while children with inability receive physiotherapy and motor coordination training services.

According to Constructivist Theory, every individual has had ability and constructs the knowledge he constructs as a subject, since childhood, therefore, that knowledge that is constructed into meaningful knowledge [4]. In term of students, constructing knowledge from an early age is a process of assimilating accommodation data to the symptoms in the Hindu Religious learning system, even started in the most basic education at level of preparation that is equivalent to Early Childhood Education.

Design of material must be compiled by teacher in accordancewith prior analysis results and student social conditions,concluded (1) Skills to create Kwangen which has learning objectives that students be able to make media of offering, practically. (2) Participation/engagement in religious activities; and (3) Learning activities, itself.

Implementation of Hindu Religious Education has more emphasis on habituation activitiesthat carried out continuously and exist in daily life, execute and observed directly by students, which includes development of moral and religious values, as well as social, emotional and independence maturity [10]. Application of this program is expected to escalate children's faith in God Almighty. Along with that, according to the flow of constructivism, learning is one of streams of cognitive psychology. Constructivism start out from opinion that learning is constructing the knowledge itself, after being understood, digested and is an act within oneself [4].

\subsection{Constraints Faced}

Constraints are things that must be passed in every human activity. Resources, such as teaching staff, an educator, is the main obstacle in applying the learning material design for children with special needs. Further, a shortage of Hindu Religious educators who have sufficient ability to teach in special schools, especially in learning Hinduism subject.

The fact is that every student who has a different special needs must be treated differently.During this study, found that another obstacle was unwillingness ofstudents. This condition occurs due to lack of motivation of parents, as well as their lack of time provided for their children with special needs.

Student's presence for coming to school to study requires parents' support, in addition to children's willingness themselves. Lack of intention of parents to participate in learning, and 
to direct their children, to be acausative factor that can diminish their children's learning enthusiasm.

To sortthe application of learning material design to be in line with the development of children with special needs, considering level of understanding, which is more slowly than normal one, therefore material presented and applied requires more repetition and direct practice on how to understand Hinduism.In term of children with hearing disorder, their memory capacity is lower than normal children, even though their long-term memory is almost no difference. The application of material presented is more about giving reinforcement in the form of images such as videos, and practice directly according to the learning theme and closer to real life.

The design of learning material and its application is more into a direct practice and individual approachesas children with special needs requires detailed assistance in learningandhabituation methods.

In line with Gagne's learning theory which describes the principles of learning, namely: (1) Continuity, providing situations or material that is similar to teacher expectations about the response of children; (2) Repetition, situation and response of students are repeated or practiced so that learning is more impeccable and longer to remember; (3) Strengthening the correct response, for example by giving a reward, to maintain and strengthen the response; (4) Positive motivation and self-confidence in learning; (5) Availability of complete subject matter to provoking children's creativity; (6) An effort to arouse intellectual skills to learn like apperception in teaching; (7) The right strategy in activating students in learning; (8) Student's soul aspects that can be influenced by teaching factors [4].

The above learning principles, applied in school for children with special needs, are very influential in its learning process. The models, strategies and methods in teaching are suitable, and it will produce maximum results.

\subsection{Overcome the Obstacles}

Preparing subject matter in detail, and pack it, was teacher's strategy to overcome the obstacles in applying the design of learning material in classroom. For example, a printed out image of sample material images such as Hindu's Gods, images of religious ceremonial media, pictures of flower used in offerings, type of incense, and many more. This simple way made studenthappy and had understanding of the meaning of worship.

Student were easily mimic how to payer since they got used to and have been doing it. Preparation class that is equivalent to kindergarten, up to students in Senior High (SMALB) was combined in one class.

Different materials were given to junior and senior high students who are familiar with Hindu's Gods. The material presented by teacher in the form of hardcopy, especially for mentally disorder students (Tuna Grahita).

Student activeness in learning is a real effort made by religious teachers in preparing religious subject matter with all the limitations at Government School for Student with Special Needs (SLB) Negeri Pembina Mataram. All materials were packaged according to the needs of students so that children know well the learning goal of their particular material.

Learning process was in accordance to the student. A sign of flatness, children boredom, unfocused, were the limit. Students with special needs are unable to learn according to the specified hours. Children must be invited to play for those classified as autistic verbal. They grasp and respond to the lesson by applying what was involved by teacher. 
Educators, accordance to the theory, is giving an action to students with their prior knowledge so that responses arose which impressed on their souls. A pleasant circumtances will strengthen behavior stimulus, arises an action. Conversely, debilitating situations result in aggravation and arising antipathy. A repetitive and entertaining practises will emergence a right response. Management of the school put an efforts on providing a suitable learning environment even though expectations in learning cannot be achieved optimally.

\section{Conclusion}

Government Schools of SLB (Sekolah Luar Biasa) Pembina in Mataram City as one of schools that cater education for students with special needs incommunication disorders (Tuna Rungu), slow learner (Tuna Grahita), children with physically disabled (muscular and skeletal system disorders), Autism and other physical disorders.

Application design of Hindu Religious learning material that is varied with media images and videos, including realobjects, referring to regular school curriculum, where design of learning materials is composed and applied into special education andcurriculum that adapts to conditions of students with special needs. Habituationmethods become a mainstay in learning.

Constraints faced by Hindu Religious teachers, who concurrently as classroom teachers, in designing learning materials and learning processes are by the number of learning groups of students. Having 4 categories of impairment, namely mental retardation, disability, hearings impaired, and autistic, are the main obstacles in designing learning materials. At the stage of application design learning material in classroom, it really makes learning disrupted and less effective.Efforts made by strive to prepare material designs according to the needs of students and synergize with parents of students in the learning process.

Teacher's dedication with all its limitations synergizes with parents of students, would be able to support children with special needs in knowing their religion, be able to practice religious practices and have a good character.

\section{References}

[1] Delphie, B. (2006). b, Pembelajaran Anak Tunagrahita: Suatu Pengantar dalam Pendidikan Inklusi, Bandung: PT. Refika Aditama.

[2] Munthe, B. (2009). Desain pembelajaran. Yogyakarta: Pustaka Insan Madani.

[3] Mantra, I. B. (1983). Tata Susila Hindu Dharma. Parisada Hindu Dharma Pusat.

[4] Siregar, E., \& Hartini, N. Teori Belajar dan Pembelajaran. 2014. Bogor: Ghalia Indonesia

[5] Suyadi (2013). Teori Pembelajaran anak Usia Dini. PT Remaja Rosdakarya Bandung.

[6] Taruna, M. M. (2010). Pelaksanaan Pendidikan Agama Pada SD-LB B Sidakarya Kota Denpasar. Analisa: Journal of Social Science and Religion, 17(1), 131-144.

[7] Team Penyusun (2007). Panduan PengenalanKurikulum. KTSP

[8] Titib, I. M., \& Widyantara, I. G. B. (2003). Menumbuhkembangkan pendidikan budhi pekerti pada anak: perspektif agama Hindu. Parisada Hindu Dharma Indonesia Pusat: Ganeca Exact.

[9] Titib, I. M. (2007). Weda Sabda Suci. Surabaya: Paramita.

[10] Titib, I. M. (2007). Studi Agama Hindu. IHDN Denpasar.

[11] Undang-Undang, R. I. (2007). Nomor 20 Tahun 2003 Tentang Sistem Pendidikan Nasional. Yogyakarta: Pustaka Pelajar.

[12] Yamin, M. (2009). Desain pembelajaran berbasis tingkat satuan pendidikan. Jakarta: Gaung Persada Press. 